\title{
Genotoxicity Evaluation of Commercially Available Acid Red Dye by Comet Assay in Fish (Cyprinus Carpio)
}

\author{
V. Deepa ${ }^{1 *}$, T. N. Sathya ${ }^{1}$, P. Balakrishna Murthy ${ }^{1} \&$ P. Neelakanta Reddy ${ }^{2}$ \\ ${ }^{1}$ International Institute of Biotechnology and Toxicology, Kanchipuram district, PIN 601 301, Padappai, India \\ ${ }^{2}$ Bio-organic Chemistry Laboratory, Central Leather Research Institute, PIN 600 020, Adayar, Chennai, India
}

(Received May 22, 2010; Accepted August 20, 2010)

\begin{abstract}
Genotoxicity of commercially available acid red dye on fish was evaluated. Fish were exposed to various concentrations of the dye and gill processed for comet assay. Nucleoids were visually scored and categorized into various damage degrees. Significant increase $(\mathrm{p}<0.05)$ in the percentage and distribution of damaged nucleoids was recorded in all dye-treated groups over control. DNA damage scores (AU) increased with exposure concentrations and dose-response was observed at higher doses. From the results it is concluded that commercially available acid red dye is potentially genotoxic to fish. The results are preliminary and further studies are warranted to acknowledge this effect.
\end{abstract}

Keywords: acid red, commercial dyes, genotoxicity, comet assay.

\section{RESUMO}

\section{Avaliação da Genotoxicidade do Corante Vermelho Ácido por Ensaio Cometa em Peixe (Cyprinus Carpio)}

A genotoxicidade do corante vermelho ácido foi avaliada em peixe. Os peixes foram expostos a várias concentrações do corante e as suas guelras utilizadas no ensaio cometa. Nucleotídeos foram visualmente mensurados e categorizados em vários graus de dano. Foi registrado um aumento significativo $(p>0,05)$ na percentagem e distribuição do dano nos nucleotídeos para todos os grupos de exposição ao corante em relação ao controle. O dano de DNA (AU) aumentou com o aumento da concentração de exposição e uma dose-resposta foi observada nas altas dosagens. Os resultados indicam que o corante comercial vermelho ácido é potencialmente genotóxico ao peixe. Os resultados são preliminares e mais estudos são necessários para confirmar os efeitos observados.

Palavra-chave: vermelho ácido, corantes comerciais, genotoxicidade, ensaio cometa.

\footnotetext{
* Corresponding author: Deepa Venkataramulu, e-mail: deepasabarish@gmail.com.
} 


\section{INTRODUCTION}

Wastewater from the textile industry is a complex mixture of many polluting substances ranging from organochlorine-based pesticides to heavy metals associated with dyes and the dyeing process (Correia et al., 1994). Inefficiencies in dyeing result in discharge of large amounts of the dyestuff and contamination of surface water with these effluents from the textile-dye and dyestuff industry represent a serious ecological problem. Extensive usage of commercial dyes has been observed in various rural sectors of India. Unfortunately, these commercial dyes do not have any information with respect to their chemical structure, purity or composition; continuous use of such dyes can lead to serious consequences to exposed organisms (Mathur et al., 2005). Acid red belongs to the class of acid dyes, which are widely used in dyeing of textiles especially protein fibers. So far, textile dyes of known and unknown purity have been tested in in vitro (Bakshi \& Sharma, 2003, Mathur et al., 2005, Tsuboy et al., 2007, Mansour et al., 2009) and in vivo test systems (Rajaguru et al., 1999) for genotoxicity in various test systems. Comet assay was first applied to ecotoxicology about 15 years ago and it as become one of the popular tests for detecting strandbreaks in aquatic animals through in vitro, in vivo and in situ exposures (Mitchelmore \& Chipman, 1998, Cotelle \& Fierard, 1999, Lee \& Steinert, 2003, Rajaguru et al., 2003, Ohe et al., 2004). Fish is an excellent model for detection of mutagenicity or carcinogenicity since they metabolize, concentrate and store water borne pollutants (Al-sabti, 1995). Hitherto, there is not much data on the effect of commercial dyes on the genetic integrity of aquatic organisms like fish. In the present study, the alkaline comet assay was used to assess the genotoxicity of commercial acid red dye in common carp.

\section{MATERIALS AND METHODS}

Acid red dye was obtained commercially from a local market in Chennai (India), although no data on purity, composition or chemical structure are available. Low melting and normal melting agarose were obtained from Sigma-aldrich (USA); all other chemicals were obtained from Hi-media, Mumbai (India). Common carp Cyprinus carpio was obtained from a commercial fish farm and quarantined for one month in cement tanks, following 10 days of acclimatization in glass aquaria; hey were fed with commercial fish feed. Feed was withdrawn
24 hours prior to exposure. The physico-chemical parameters of the water were recorded: $\mathrm{pH}$ (7.3-7.6), dissolved oxygen (7.4-7.8 mg. $\mathrm{L}^{-1}$ ), hardness (185 mg. $\left.\mathrm{L}^{-1}\right)$ and temperature $\left(27 \pm 1{ }^{\circ} \mathrm{C}\right)$. Groups of 10 fishes were exposed to $6.25,12.5,25$, 50 or $100 \mathrm{mg} . \mathrm{L}^{-1}$ of the dye in a static system. Cyclophosphamide (10 mg. $\mathrm{L}^{-1}$ ) was used as reference mutagen. At 96 hours, live fish from all groups were sacrificed using ether, dissected and gill tissue was collected in ice cold Phosphate-Buffered Saline containing $10 \%$ DMSO; homogenized with a micro pestle and allowed to settle. The supernatant containing single cells was used for comet assay. Comet assay was performed as described by Singh et al. (1988). Briefly, 1 hour lysis, 20 minutes alkaline unwinding and 20 minutes electrophoresis $(300 \mathrm{~mA} 25 \mathrm{~V})$ was performed. Ethidium bromide-stained nucleoids were examined with a fluorescent microscope (Carl Zeiss, Germany). Hundred comets (50 comets/slide, 2 slides/fish) were scored visually as belonging to one of five classes ( 0 - undamaged, 1 - mild damage, 2 - moderate damage, 3 - severe damage, 4 - complete damage) Collins et al. (2004). Thus, the total score for 100 comets could range from 0 (all undamaged) to 400 (all damaged). The percentage of damaged cells was calculated and statistically analyzed. Arbitrary Unit used to express the extent of DNA damage was calculated as follows (Equation 1):

$$
\text { Arbitrary unit }=\sum_{i=0}^{4} N i \times i
$$

Where $N i=$ Number of cells in $i$ degree; $i=$ degree of damage $(0,1,2,3,4)$.

\section{RESULTS}

The number of nucleoids in each damage grade, the percentage of damaged nucleoids and DNA damage score are presented in Table 1. Significant increases $(p<0.05)$ in the percentage of damaged nucleoids were observed in all the dye-treated groups. Frequency histogram of the damage grade in control and dye-treated group are shown in Figure 1. The distributions in the damage grades in all the dye-treated groups were significantly different from control $(\mathrm{p}<0.05)$. DNA damage scores (expressed as Arbitrary Units), increased as the exposure concentrations increased and dose-response was observed (Figure 2). The results reveal that commercially

Table 1 - Nucleoids in various damage degrees, percentage of DNA damage and DNA damage (AU).

\begin{tabular}{|c|c|c|c|c|c|c|c|}
\hline \multirow[t]{2}{*}{ Group } & \multicolumn{5}{|c|}{$\mathrm{N}^{\circ}$ of cells in different damage degrees $\left(\mathrm{Mean}^{*} \pm \mathrm{SD}\right)$} & \multirow[t]{2}{*}{$\%$ DNA damage } & \multirow{2}{*}{$\begin{array}{c}\text { DNA damage score } \\
(\mathrm{AU})\end{array}$} \\
\hline & 0 & 1 & 2 & 3 & 4 & & \\
\hline Control (water) & $82 \pm 4.2$ & $6 \pm 2.0$ & $12 \pm 3.4$ & $0 \pm 0.0$ & $0 \pm 0.0$ & 18 & 31 \\
\hline $6.25 \mathrm{mg} . \mathrm{L}^{-1}$ & $4 \pm 2.7$ & $21 \pm 7.3$ & $18 \pm 5.8$ & $35 \pm 3.1$ & $22 \pm 3.1$ & $96^{*}$ & 251 \\
\hline $12.5 \mathrm{mg} \cdot \mathrm{L}^{-1}$ & $5 \pm 3.1$ & $17 \pm 5.3$ & $24 \pm 3.0$ & $21 \pm 2.2$ & $34 \pm 3.9$ & $95^{*}$ & 264 \\
\hline $25 \mathrm{mg} . \mathrm{L}^{-1}$ & $4 \pm 2.1$ & $13 \pm 2.9$ & $14 \pm 3.2$ & $28 \pm 3.3$ & $40 \pm 3.8$ & $96^{*}$ & 287 \\
\hline $50 \mathrm{mg} \cdot \mathrm{L}^{-1}$ & $0 \pm 0.5$ & $3 \pm 1.7$ & $7 \pm 1.8$ & $23 \pm 5.1$ & $67 \pm 5.2$ & $100^{*}$ & 353 \\
\hline $100 \mathrm{mg} \cdot \mathrm{L}^{-1}$ & $0 \pm 0.4$ & $0 \pm 0.5$ & $2 \pm 1.2$ & $9 \pm 5.5$ & $89 \pm 5.7$ & $100^{*}$ & 386 \\
\hline $\mathrm{CP}\left(10 \mathrm{mg} \cdot \mathrm{L}^{-1}\right)$ & $0 \pm 0.5$ & $0 \pm 0.4$ & $1 \pm 1.1$ & $1 \pm 0.7$ & $98 \pm 1.7$ & $100^{*}$ & 396 \\
\hline
\end{tabular}

$* \mathrm{p}<0.05$ - (with control: $\chi^{2}$ test), AU- Arbitrary Units, ${ }^{*}$-Mean value from three independent experiments. 


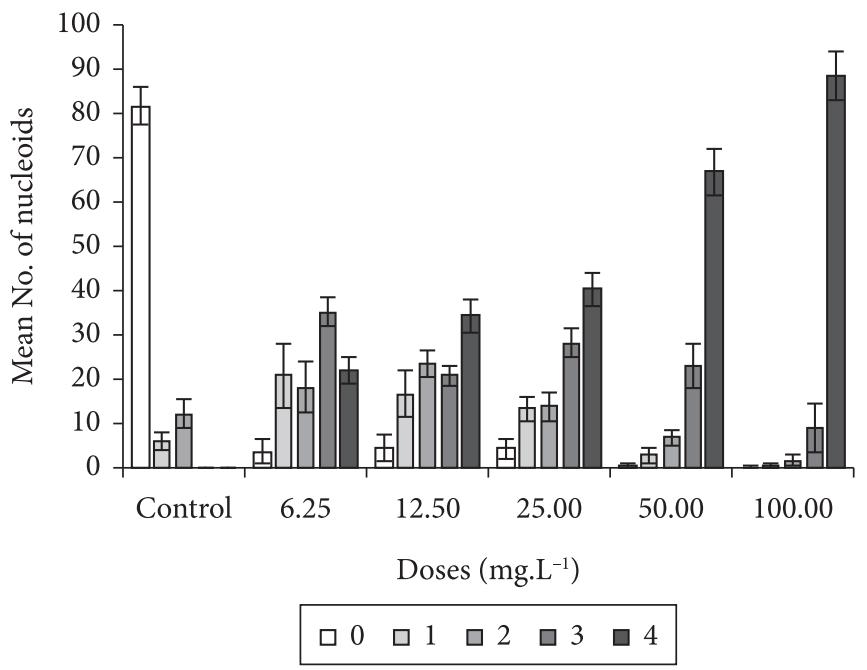

Figure 1 - DNA damage ( \pm Standard deviation) in each group (0 - no damage, 1 - mild damage, 2- moderate damage, 3- severe damage and 4 - complete damage) for control and different concentrations of the dye. $* \mathrm{p}<0.05-$ Kruskal-Wallis test (over control).

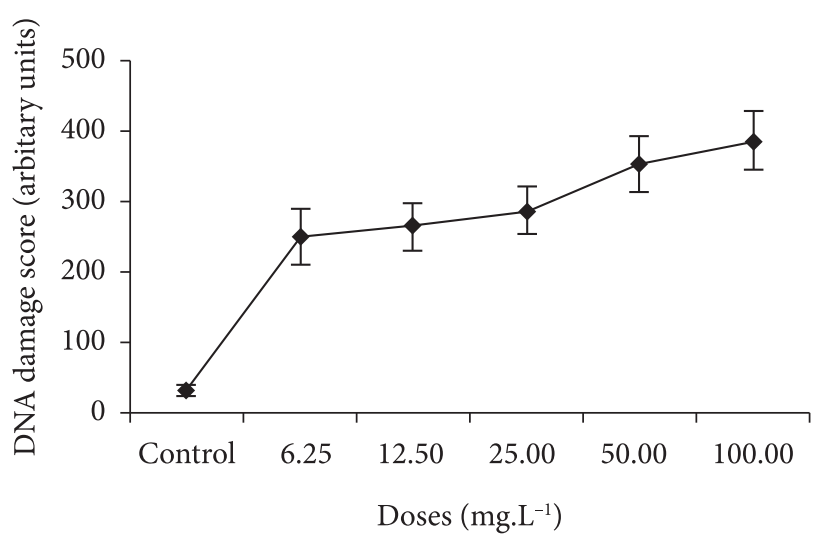

Figure 2 - Dose response ( \pm Standard deviation) upon treatment with different concentrations of the dye $(n=30,10$ fish/group/experiment).

available acid red dye is genotoxic to fish at all doses tested and a dose response was achieved at higher doses.

\section{DISCUSSION}

Azo dyes are the largest group of dyes used in textile industry constituting $60-70 \%$ of all dyestuffs produced. They have one or more azo groups $(\mathrm{R}-\mathrm{N}=\mathrm{N}-\mathrm{R})$ with aromatic rings substituted by sulfonate groups. These complex aromatic substituted structures make conjugated system and are responsible for intense color, high water solubility and resistance to degradation under natural conditions. Azo dyes and their breakdown products are cytotoxic or carcinogenic (Khehra et al., 2006).

Mitchelmore \& Chipman (1998) recommended that DNA strand breaks, particularly as measured by the comet assay, act as a biomarker of genotoxicity in fish and other aquatic species. In vivo comet data on fish were obtained with redbreast sunfish, hard head cat fish, bullhead and carp (Pandragi et al., 1995). When genotoxic agents interact with the DNA, modifications like breaks, adducts are encountered; the levels increase when the repair system enzymatically removes these damaged nucleotides. When unrepaired or wrongly repaired, the integrity of the DNA is disrupted and may lead to mutations and neoplastic transformations.

In the present study, DNA damaging potential of commercial acid red dye, an azo dye was assessed using comet assay. Acid red dye induced DNA damage in all the concentrations tested showing the ability of the chemical to interact with the DNA of fish. The damage profile was consistent at lower doses and a dose-response was achieved only at higher doses. Sumathi et al. (2001) reported such response in common carp exposed to textile-dyeing effluent for 3 days using comet assay. Single strand breaks is a direct indication of genotoxicity (Sardas et al., 1998) and can be efficiently assessed by comet assay. They arise from incomplete excision repair of DNA adducts cross-links and alkali-labile sites (Pfuhler \& Wolf, 1996; De Boeck et al., 2000). In this case, the DNA damage recorded can be attributed to the metabolic intermediates of the dye tested.

From the present study, it is concluded that the commercially available acid red dye is potentially genotoxic to fish. The results are preliminary and further studies are needed to explore the precise mechanisms of genotoxicity and possible repair. The anonymity in the chemical structure, purity and other manufacturing processes makes these compounds difficult for evaluations. Nevertheless, continued usage of commercial dyes with such cryptic molecular toxicity can be detrimental to the aquatic system and hence invite attention. The alkaline comet assay can be a useful tool for identifying the potential genotoxicity of these chemicals to the aquatic biota.

Acknowledgement - We are grateful to the Management of IIBAT, Prof R. Sridhar for his suggestions and Mr. A. Goparaju for his skilled assistance in statistical analysis.

\section{REFERENCES}

AL-SABTI, K. \& METCALFE, C. D., 1995, Fish micronuclei for assessing genotoxicity in water. Mutat. Res., 343:121-135. doi: 10.3923/rjes.2007.56.63.

BAKSHI, D. K. \& SHARMA, P., 2003, Genotoxicity of textile dyes evaluated with Ames test and rec-assay. J. Environ. Pathol. Toxicol. Oncol., 22:101-9.

COLLINS, A. R., 2004, The Comet assay for DNA damage and repair: principles, applications and limitation. Mol. Biotechnol., 26:249-260.

CORREIA, V. M., STEPHANSON, T. \& JUDD, S. J., 1994, Characterization of textile wastewaters a review. Environ Technol., 15:917-929.

COTELLE, S. \& FE'RARD, J. F., 1999, Comet assay in genetic ecotoxicology: a review. Environ. Mol. Mutagen., 34:246-255.

DE BOECK, M., TOUI, N., DE VISSCHER, G., VANDE, P. A. \& KIRSCH-VOLDERS, M., 2000, Validation and implementation of an internal standard in comet assay analysis. Mut. Res., 469:181-197.

KHEHRA, M. S., SAINI, H. S., SHARMA, D. K., CHADHA, B. S., CHIMNI, S. S., 2006, Biodegradation of azo dye C.I. Acid Red 88 by an anoxic-aerobic sequential bioreactor. Dyes Pigm., 70:1-7.

LEE, R. F. \& STEINERT, S., 2003, Use of the single cell gel electrophoresis/comet assay for detecting DNA damage in 
aquatic (marine and freshwater) animals. Mutat. Res., 544:43-64. doi: 10.1016/S1383-5742(03)00017-6.

MANSOUR, H. B., MOSRATI, R., CORROLER, D., GHEDIRA, K., BARILLIER, D. \& GHEDIRA, L., 2009, Mutagenicity and genotoxicity of acid yellow 17 and its biodegradation products. Drug Chem. Toxicol., 32:222-229.

MATHUR, N., BHATNAGAR, P. \& BHAKRE, P., 2005, Assessing the mutagenicity of textile dyes from Pali (Rajasthan) using Ames bioassay. Appl. Ecol. Environ. Res., 4:111-118.

MITCHELMORE, C. L. \& CHIPMAN, J. K., 1998, DNA strand breakage in aquatic organisms and the potential value of the comet assay in environmental monitoring. Mutat. Res., 399:135-147.

OHE, T., WATANABE, T. \& WAKABAYASHI, K., 2004, Mutagens in surface waters: a review. Mutat. Res., 567:109-149.

PANDRANGI, R., PETRAS, M., RALPH, S. \& VRZOC, M., 1995, Alkaline single cell gel (comet) assay and genotoxicity monitoring using bullheads and carp. Environ. Mol. Mut., 26:345-356.

PFUHLER, S. \& WOLF, H. U., 1996, Detection of DNA-cross linking agents with the alkaline comet assay. Environ. Mol. Mut., 27:196-201. doi: 10.1016/S0091-679x (01)64016-0.

RAJAGURU, P., FAIRBAIN, L. J., ASHBY, J., WILLINGTON, M. A., TURNER, S., WOOLFORD, L. A., CHINNASAMY, N. \&
RAFFERTY, J. A., 1999, Genotoxicity studies on the azo dye Direct Red 2 using the in vivo mouse bone marrow micronucleus test. Mut. Res., 444:175-180.

RAJAGURU, P., SUBA, S., PALANIVEL, M. \& KALAISELVI, K., 2003, Genotoxicity of a polluted river system measured using the alkaline comet assay on fish and earthworm tissues. Environ. Mol. Mut., 85-91. doi: 10.1002/em.10134.

SARDAS, S., KARABIYIK, L., AYGUN, N. \& KARAKAYA, A. E., 1998. DNA damage evaluated by the alkaline comet assay in lymphocytes of humans anaesthetized with isoflurane. Mut. Res., 418:1-6.

SINGH, N. P., McCOY, M. T., TICE, R. R. \& SCHNEIDER, E. L., 1988, A simple technique for quantitation of low levels of DNA damage in individual cells. Exp. Cell. Res., 175:184-191.

SUMATHI, M., KALAISELVI, K., PALANVIEL, M. \& RAJAGURU, P., 2001, Genotoxicity of textile dye effluent on fish (Cyprinus carpio) measured using the comet assay. Bull. Environ. Contam.Toxicol., 66:407-414. doi: 10.1007/s00128-001/0020-3.

TSUBOY, M. S., ANGELI, J. P., MANTOVANI, M. S., KNASMULLER, S., UMBUZEIRO, G. A. \& RIBEIRO, L. R., 2007, Genotoxic, mutagenic and cytotoxic effects of the commercial dye CI Disperse Blue 291 in the human hepatic cell line HepG2. Toxicol. In. Vitro., 21(8):1650-1655. doi:10.1016/j. tiv.2007.06.02. 